This is a post-peer-review, pre-copyedit version of an article published in Chemico-Biological Interactions. The final authenticated version is available online at: http://dx.doi.org/10.1016/j.cbi.2016.02.019

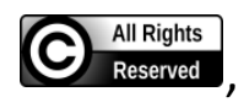

(C) 2016, Elsevier Ireland Ltd. 


\title{
Structural differences in diarylheptanoids analogues from Alnus viridis and Alnus glutinosa influence their activity and selectivity towards cancer cells
}

Jelena Dinić ${ }^{a^{*}}$, Miroslav Novakovićb ${ }^{b}$ Ana Podolski-Renić ${ }^{a}$, Vlatka Vajs ${ }^{b}$, Vele Teševićc, Aleksandra Isaković ${ }^{\mathrm{d}}$, Milica Pešića

${ }^{a}$ Institute for Biological Research, Department of Neurobiology, University of Belgrade, Despota Stefana 142, Belgrade, Serbia

${ }^{b}$ Institute for Chemistry, Technology and Metallurgy, University of Belgrade, Studentski trg 12-16, Belgrade, Serbia

${ }^{c}$ Faculty of Chemistry, University of Belgrade, Studentski trg 12-16, Belgrade, Serbia

${ }^{d}$ Faculty of Medicine, University of Belgrade, Doktora Subotića 8, Belgrade, Serbia

\author{
*Corresponding author \\ Jelena Dinić, $\mathrm{PhD}$ \\ Institute for Biological Research, Department of Neurobiology, University of Belgrade, Despota \\ Stefana 142, Belgrade, Serbia \\ Phone: +381112078406 \\ Fax: +381112761433 \\ E-mail: jelena.dinic@ibiss.bg.ac.rs
}




\section{Abstract}

Diarylheptanoids represent a group of plant secondary metabolites that possess multiple biological properties and are increasingly recognized for their therapeutic potential. A comparative study was performed on structurally analogous diarylheptanoids isolated from the bark of green (Alnus viridis) and black alder (Alnus glutinosa) to address their biological effects and determine structure-activity relationship. The structures and configurations of all compounds were elucidated by NMR, HR-ESI-MS, UV and IR. Diarylheptanoids actions were studied in human non-small cell lung carcinoma cells (NCI-H460) and normal keratinocytes (HaCaT). A. viridis compounds 3v, 5v, 8v and 9v that possess a carbonyl group at C-3 were considerably more potent than compounds without this group. A. viridis/A. glutinosa analogue pairs, 5v/5g and 9v/9g, which differ in the presence of $3^{\prime}$ and $3^{\prime \prime}-\mathrm{OH}$ groups, were evaluated for anticancer activity and selectivity. 5v and 9v that do not possess $3^{\prime}$ and $3^{\prime \prime}-\mathrm{OH}$ groups showed significantly higher cytotoxicity compared to analogues $\mathbf{5 g}$ and $\mathbf{9 g}$. In addition, these two A. viridis compounds induced a more prominent apoptosis in both cell lines and an increase in subG $_{0}$ cell cycle phase, compared to their A. glutinosa analogues. $\mathbf{5 v}$ and $\mathbf{9 v}$ treatment triggered intracellular superoxide anion accumulation and notably decreased mitochondrial transmembrane potential. In HaCaT cells, 9v and $\mathbf{9 g}$ with a 4,5 double bond caused a more prominent loss of mitochondrial transmembrane potential compared to $\mathbf{5 v}$ and $\mathbf{5 g}$ which possess a 5-methoxy group instead. Although green alder diarylheptanoids $\mathbf{5 v}$ and $\mathbf{9 v}$ displayed higher cytotoxicity, their analogues from black alder $5 \mathrm{~g}$ and $\mathbf{9 g}$ could be more favorable for therapeutic use since they were more active in cancer cells than in normal keratinocytes. These results indicate that minor differences 
in the chemical structure can greatly influence the effect of diarylheptanoids on apoptosis and redox status and determine their selectivity towards cancer cells.

\section{Keywords}

diarylheptanoids; structure-activity relationship; reactive oxygen species; mitochondrial transmembrane potential

\section{Abbreviations}

AV: Annexin-V-FITC

DHE: Dihydroethidium

JC-1: 5,5',6,6'-Tetrachloro-1,1',3,3'-tetraethylbenzimidazolocarbocyanine iodide

PI: Propidium iodide

ROS: Reactive oxygen species

SAR: structure-activity relationship

SRB: Sulforhodamine B

$\Delta \Psi_{\mathrm{m}}$ : Mitochondrial transmembrane potential 


\section{Introduction}

Genus Alnus (alders) belongs to Betulaceae family. It comprises over 30 species of monoecious trees and shrubs distributed throughout the North Temperate Zone with a few species in Central America and the northern Andes. Green alder (Alnus viridis (Chaix) DC.), is a bush, 3-5 m tall, found in the mountains of central Europe (Alps) and Balkan Peninsula [1]. In Serbia, Alnus viridis ssp. viridis can be found mostly in the east regions (Mt. Stara Planina), near creeks, at altitude 1300-2100 m [2]. Alnus glutinosa (L.) Gaertn. (black alder, European alder) tree is found in Europe, the Mediterranean, southeastern Asia, the Caucasus Mountains, and western Siberia [2]. Multiple pharmacological studies have shown that extracts of various Alnus species display antiinflammatory, antiobesity and antioxidative effects [3-6].

Diarylheptanoids are phenolic compounds typically found in the genus Alnus. They consist of two aryl groups joined by a heptane chain in the main skeleton and there is a variety of substituents carried by diarylheptanoids such as hydroxyl, methoxy, monosaccharide or disaccharide that can significantly influence their biological activity. They have been reported to display antioxidative [7-8], antibacterial [9], antiviral [10], chemoprotective [11] and anticancer properties [12-13]. Diarylheptanoids isolated from A. glutinosa exhibited chemoprotective activity and antagonized the effects of doxorubicin and cisplatin in human non-small cell lung cancer cells, human keratinocytes, and peripheral blood mononuclear cells [14]. Diarylheptanoids treatment reduced mitochondrial fragmentation associated with application of doxorubicin, inhibited generation of cisplatin-induced free radicals and increased mRNA expression of Mn-SOD and HIF-1 $\alpha$. [14]. Additionally, diarylheptanoids from A. glutinosa were shown 
to prevent doxorubicin-induced cell death by activating autophagy and protect human keratinocytes against doxorubicin-induced DNA damage [15]. Several compounds including platyphylloside, alnuside B and hirsutenone, were reported to display strong anticancer activity and significant selectivity towards the multidrug resistant lung cancer cells [16].

A comparative study was performed on a series of diarylheptanoids isolated from the bark of green alder and previously isolated diarylheptanoids from the black alder bark [16]. Our goal was to address their biological effect on human cancer and normal cells and determine their structure-activity relationship (SAR). Based on the similarities in their structure and the presence or absence of different moieties, compounds from both species were grouped into pairs of analogues and their biological activity was compared. We investigated the chemical structure-dependent effect of diarylheptanoids, including one novel compound isolated from A. viridis, on cellular proliferative capacity, cell cycle, mitochondrial function and redox status.

\section{Materials and methods}

\subsection{Plant material and compounds origin}

Diarylheptanoids investigated in this work, except new compound $4 \mathbf{v}$, were previously isolated from the $\mathrm{CHCl}_{3} / \mathrm{MeOH}$ (1:1) extract of the green alder bark from Serbia [17]. For the purpose of investigation of biological activities the same compounds were isolated in higher yield using procedure given in previous work [16]. Techniques used for isolation were silica gel column chromatography followed by semipreparative reversed phase HPLC. Their structures were elucidated by means of 1D and 2D NMR, 
IR, UV and HR-ESI-MS. The experimental data regarding isolation are given in Supporting information. Diarylheptanoids analyzed in this work are 3-hydroxy-5-(4hydroxyphenyl)-1-[2-(4-hydroxyphenyl)ethyl]pentyl $\quad 6-O-\beta$-D-apiofuranosyl- $\beta$-Dglucopyranoside (1v), aceroside VIII (2v), (5S)-5-[(6- $O-\beta$-D-apiofuranosyl- $\beta$-Dglucopyranosyl)oxy]-1,7-bis(4-hydroxyphenyl)heptan-3-one $\quad(3 \mathbf{v}), \quad$ (1S)-5-(4hydroxyphenyl)-1-[2-(4-hydroxyphenyl)ethyl]pentyl $\quad 6-O-\alpha$-L-arabinofuranosyl- $\beta$-Dglucopyranoside $\quad(\mathbf{4 v}), \quad(5 S)-O$-methylplatyphyllonol $\quad(\mathbf{5 v}), \quad(1 S, 3 R)-3$-hydroxy-5-(4hydroxyphenyl)-1-[2-(4-hydroxyphenyl)ethyl]pentyl $\beta$-D-glucopyranoside (6v), (1R)-5(4-hydroxyphenyl)-1-[2-(4-hydroxyphenyl)ethyl]pentyl $\quad 6-O-\alpha$-L-arabinofuranosyl- $\beta$-Dglucopyranoside (7v), (5S)-1,7-bis(4-hydroxyphenyl)-5-[[6-O-(3.4.5-trihydroxybenzoyl)$\beta$-D-glucopyranosyl]oxy]heptan-3-one (8v) and platyphyllenone (9v), (Fig. 1A). Before the investigation of the biological activity all tested diarylheptanoids were checked for their purity by HPLC (at $280 \mathrm{~nm}$ ) and ${ }^{1} \mathrm{H}$ NMR, and it was higher than $98 \%$. Compound 4v has been newly isolated in this study and added to the investigation of biological activity. Since there is no literature data about diarylheptanoid $\mathbf{4 v}$, it was assumed that $\mathbf{4 v}$ is new secondary metabolite.

In comparison with known compound 7v [17], 4v (6 mg) exhibited NMR spectra similar to that of $\mathbf{7 v}$, with minor differences in heptane and aromatic parts of the ${ }^{13} \mathrm{C}$ NMR spectrum (Figs. S1, S2 and S3, Table S1 in Supporting information). Small differences can be explained only by R/S isomerisation, so $4 \mathbf{v}$ represents $3 S$ isomer of $7 \mathbf{v}$. $S$ configuration was determined by ${ }^{13} \mathrm{C}$ glycosidation shift rule [18-19] analyzing ${ }^{13} \mathrm{C}$ NMR spectra of $\mathbf{4 v}$ (recorded in pyridine- $\mathrm{d}_{5}$ for that purpose) and its appropriate aglicon (-)-centrolobol [20-21]. Smaller difference in chemical shifts was obtained for C-4 than 
for C-2, $\Delta \delta_{\mathrm{C} 4}<\Delta \delta_{\mathrm{C} 2}(2,7<3,2)$, referring to $S$ configuration at C-3 (Fig. S4 in Supporting information). Quasimolecular ions $[\mathrm{M}-\mathrm{H}]^{-}$at $\mathrm{m} / \mathrm{z} 593,2617$ and $[\mathrm{M}+\mathrm{Cl}]^{-}$at $\mathrm{m} / \mathrm{z} 629,2382$ confirmed supposed structure. $[\alpha]_{\mathrm{D}}$ value for $4 \mathbf{v}$ in $\mathrm{MeOH}$ was $-51.0^{\circ}$. For $7 \mathbf{v} \Delta \delta_{\mathrm{C} 4}>\Delta \delta_{\mathrm{C} 2}$ (3,5 $>2,5$, in pyridine- $\left.\mathrm{d}_{5}\right)$, referring to $R$ configuration at $\mathrm{C}-3$. $[\alpha]_{\mathrm{D}}$ for $7 \mathbf{v}$ was $-91.1^{\circ}$ [17]. Hence, $\mathbf{4 v}$ is $(1 S)-5-(4-h y d r o x y p h e n y l)-1-[2-(4-h y d r o x y p h e n y l) e t h y l] p e n t y l ~ 6-O-\alpha-$ L-arabinofuranosyl- $\beta$-D-glucopyranoside. Spectroscopic data for new compound $\mathbf{4 v}$ are given in Supporting information.

In order to obtain a more comprehensive structure-activity relationship, we included cytotoxity measurements of four diarylheptanoids isolated from the black alder bark in a previous investigation: (5S)-1,7-bis(4-hydroxyphenyl)-5-[[6-O-[(E)-3-(4hydroxyphenyl)-1-oxo-2-propen-1-yl]- $\beta$-D-glucopyranosyl]oxy]heptan-3-one (3g), 5(S)$O$-methylhirsutanonol (5g), platyphylloside (8g), and hirsutenone (9g) (Fig. 1B) [16]. 5(S)-O-methylhirsutanonol (5g) [5] and hirsutenone (9g) [22] are known plant metabolites whose biological activities were further explored and compared to diarylheptanoids from A. viridis in support of a more detailed SAR study.

\subsection{Chemicals}

RPMI 1640 medium, DMEM medium, penicillin-streptomycin solution, antibiotic-antimycotic solution, L-glutamine and trypsin/EDTA were purchased from PAA, Vienna, Austria. Fetal bovine serum (FBS), dimethyl sulfoxide (DMSO), sulforhodamine $\quad \mathrm{B} \quad(\mathrm{SRB}) \quad$ and $5,5^{\prime}, 6,6^{\prime}$-Tetrachloro-1,1',3,3'tetraethylbenzimidazolocarbocyanine iodide (JC-1) were obtained from Sigma-Aldrich Chemie GmbH, Germany. Propidium Iodide (PI) and Annexin-V-FITC (AV) were 
purchased from Abcam, Cambridge, UK. Dihydroethidium (DHE) was obtained from Molecular Probes ${ }^{\circledR}$, Invitrogen, CA, USA.

\subsection{Cell culture}

NCI-H460 cell line (human non-small cell lung cancer) was purchased from the American Type Culture Collection, Rockville, MD. NCI-H460 cells were maintained in RPMI 1640 supplemented with 10\% FBS, 2 mM L-glutamine, $4.5 \mathrm{~g} / \mathrm{L}$ glucose, 10,000 $\mathrm{U} / \mathrm{mL}$ penicillin, $10 \mathrm{mg} / \mathrm{mL}$ streptomycin, $25 \mathrm{mg} / \mathrm{mL}$ amphotericin $\mathrm{B}$ solution at $37^{\circ} \mathrm{C}$ in a humidified 5\% $\mathrm{CO} 2$ atmosphere. $\mathrm{HaCaT}$ cell line (normal human keratinocytes obtained from CLS - Cell Lines Service, Eppelheim, Germany) was generous gift from Prof. Andra Jorg, Division of Biophysics, Research Center Borstel, Leibniz-Center for Medicine and Biosciences, Borstel, Germany. HaCaT cells were cultured in DMEM supplemented with $10 \%$ FBS, $4 \mathrm{~g} / \mathrm{L}$ glucose, L-glutamine $(2 \mathrm{mM})$ and $5000 \mathrm{U} / \mathrm{ml}$ penicilin, $5 \mathrm{mg} / \mathrm{mL}$ streptomycin solution.

\subsection{Cytotoxicity by SRB assay}

NCI-H460 and $\mathrm{HaCaT}$ cells grown in $25 \mathrm{~cm}^{2}$ tissue flasks were trypsinized, seeded into 96-well tissue culture plates and incubated overnight. The cells were then treated for $72 \mathrm{~h}$ with increasing concentrations of diarylheptanoids $1 \mathbf{v}-9 \mathbf{v}$ from A. viridis. The SRB assay was performed as previously described by Skehan et al. [23]. Briefly, the cells in 96-well plates were fixed in $50 \%$ trichloracetic acid $\left(50 \mathrm{ml} /\right.$ well) for $1 \mathrm{~h}$ at $4{ }^{\circ} \mathrm{C}$, rinsed in tap water and stained with $0.4 \%(\mathrm{w} / \mathrm{v}) \mathrm{SRB}$ in $1 \%$ acetic acid $(50 \mathrm{ml} / \mathrm{well})$ for 30 minutes at room temperature. The cells were then rinsed three times in $1 \%$ acetic acid 
to remove the unbound stain. The protein-bound stain was extracted with $200 \mathrm{ml} 10 \mathrm{mM}$ Tris base ( $\mathrm{pH} 10.5)$ per well. The optical density was read at $540 \mathrm{~nm}$ with correction at $670 \mathrm{~nm}$ in a LKB 5060-006 micro plate reader (Vienna, Austria).

Growth inhibition (I) was determined according to the following equitation:

$$
I=\left(1-A_{\text {treated }} / A_{\text {untreated }}\right) \times 100
$$

where $\mathrm{A}$ is absorbance.

$\mathrm{IC}_{50}$ value was defined as a concentration of each drug that inhibited cell growth by $50 \%$. $\mathrm{IC}_{50}$ was calculated by linear regression analysis using Excel software.

\subsection{Cell death detection}

The percentages of apoptotic, necrotic and viable cells were determined by Annexin-V-FITC (AV) and propidium iodide (PI) labeling. NCI-H460 and HaCaT cells were incubated overnight in 6-well plates and subjected to single treatments with $15 \mu \mathrm{M}$ and $45 \mu \mathrm{M}$ diarylheptanoids. After $48 \mathrm{~h}$, the attached and floating cells were collected by centrifugation. AV/PI staining was performed according to manufacturer's instructions and cells were analyzed within $1 \mathrm{~h}$ by flow-cytometry. The fluorescence intensity (green FL1-H and red FL2-H) was measured on FACSClibur flow-cytometer (Becton Dickinson, Oxford, United Kingdom). In each sample, 10,000 cells were recorded (gated to exclude cell debris), and the percentages of viable (AV-PI-), early apoptotic (AV+ PI-

), apoptotic and necrotic (AV+ PI+), and already dead (AV-PI+) cells were analyzed by CellQuest Pro data analysis software. 


\subsection{Analysis of cell cycle distribution}

Unsynchronized NCI-H460 and HaCaT cells were plated in 6-well plates and incubated overnight. The effect of diarylheptanoids on cell cycle distribution was studied after $48 \mathrm{~h}$. Briefly, the attached were trypsinized and along with the floating cells collected by centrifugation, washed in phosphate buffered saline (PBS) and fixed in 70\% ethanol for $48 \mathrm{~h}$ at $-20{ }^{\circ} \mathrm{C}$. After fixation, the cells were washed in PBS and pretreated with $50 \mathrm{mg} / \mathrm{ml}$ of RNAse-A at $37{ }^{\circ} \mathrm{C}$ for $15 \mathrm{~min}$. Then, PI was added to final concentration of $50 \mathrm{mg} / \mathrm{ml}$. After $30 \mathrm{~min}$ flow-cytometric analysis was performed on the FACSCalibur flow-cytometer (Becton Dickinson, Oxford, United Kingdom). A minimum of 10,000 events were collected for each experimental sample. Cell cycle distribution was determined automatically in Mod-FIT (Verity Software House, Inc). The validity of the data analysis model was verified using the R.C.S.value (reduced Chi2, R.C.S. $<15 \%$ ).

\subsection{Superoxide anion detection by flow cytometry}

Flow-cytometric analysis of DHE fluorescence intensity was used to detect superoxide anion level in cells. NCI-H460 and HaCaT cells were incubated overnight in 6-well plates, and then treated with $15 \mu \mathrm{M}$ diarylheptanoids. After $24 \mathrm{~h}$, adherent cells were harvested by trypsinization and incubated in adequate medium with $1 \mu \mathrm{M}$ DHE, a superoxide indicator dye, for $30 \mathrm{~min}$ at $37{ }^{\circ} \mathrm{C}$ in the dark. Cells were subsequently washed twice in PBS and DHE fluorescence was analyzed on a FACSClibur flowcytometer (excitation $488 \mathrm{~nm}$, and emission $585 \mathrm{~nm}$, FL2-H channel). Mean fluorescence intensity (MFI) was calculated after correction for auto-fluorescence. 


\subsection{Mitochondrial transmembrane potential detection by flow cytometry}

Mitochondrial transmembrane potential $\left(\Delta \Psi_{\mathrm{m}}\right)$ was assessed by flow-cytometric measurement of JC-1 fluorescence. NCI-H460 and HaCaT cells were incubated overnight in 6-well plates, and then treated with $15 \mu \mathrm{M}$ diarylheptanoids for $24 \mathrm{~h}$. Cells were trypsinized, resuspended in $500 \mu \mathrm{L}$ of media containing $2 \mu \mathrm{M} \mathrm{JC}-1$ and incubated for 30 min at $37{ }^{\circ} \mathrm{C}$ in the dark. After washing twice in PBS, both red and green fluorescence emissions were detected and their ratio analyzed on a FACSClibur flow-cytometer (excitation $488 \mathrm{~nm}$, emission $530 \mathrm{~nm}$ for FL1-H channel and $585 \mathrm{~nm}$ for FL2-H channel).

\subsection{Fluorescence microscopy}

NCI-H460 and HaCaT cells were seeded in 4-well chamber slides (Nunc, Naperville, IL, USA) and allowed to grow at $37{ }^{\circ} \mathrm{C}$ overnight before being treated with $15 \mu \mathrm{M}$ diarylheptanoids for $24 \mathrm{~h}$ at $37^{\circ} \mathrm{C}$. To detect superoxide anion, cells were washed in PBS and labeled with $1 \mu \mathrm{M}$ DHE for $30 \mathrm{~min}$ at $37^{\circ} \mathrm{C}$. Live NCI-H460 and HaCaT cells were examined under the Zeiss Axiovert fluorescent microscope (Carl Zeiss Foundation, Oberkochen, Germany) using an AxioVision4.8 software.

To observe $\Delta \Psi_{\mathrm{m}}$, cells were washed in PBS and labeled with $2 \mu \mathrm{M}$ JC-1 for 30 min at $37^{\circ} \mathrm{C}$. JC-1 is a cationic dye whose accumulation in mitochondria is dependent on the mitochondrial membrane potential [24]. When in monomeric form, JC-1 fluoresces in green $(525 \mathrm{~nm})$, which can be used to measure mitochondrial density in cells. Under normal conditions, mitochondria-accumulated JC-1 forms aggregates that fluoresce in red (590 nm). Disruption of mitochondrial membrane integrity and loss of the potential 
reduces the amount of aggregates and decreases red fluorescence. Live NCI-H460 and HaCaT cells labeled with JC-1 were examined under the Zeiss Axiovert fluorescent microscope.

\subsection{Statistical analysis}

Statistical analysis for SRB assay was performed in GraphPad Prism 6 software. The differences between groups were determined by a two-way ANOVA test. Statistical analysis for flow-cytometric data was performed in Mod-FIT and CellQuest Pro data analysis software. Statistical significance was accepted if $\mathrm{p}<0.05$.

\section{Results and discussion}

\subsection{Influence of diarylheptanoids' chemical structure on cell growth inhibition and} cell death

The in vitro cytotoxic activity of diarylheptanoids after $72 \mathrm{~h}$ treatment was studied in NCI-H460 and HaCaT cell lines by the SRB assay (Table 1). The effect of compounds is presented as $\mathrm{IC}_{50}$ values that correspond to the inhibited cell growth by $50 \%$. Among isolated compounds from $A$. viridis, $\mathbf{5 v}$ and $\mathbf{9 v}$ exerted the most potent cytotoxic effect with $\mathrm{IC}_{50}$ values $8.2 \mu \mathrm{M}$ and $14.4 \mu \mathrm{M}$ in NCI-H460 cells, and $8.9 \mu \mathrm{M}$ and $9.1 \mu \mathrm{M}$ in HaCaT cells, respectively. New compound $\mathbf{4 v}$ displayed the lowest cytotoxic potential $\left(\mathrm{IC}_{50}=388.9 \mu \mathrm{M}\right.$; Table 1$)$. We compared $\mathrm{IC}_{50}$ values of diarylheptanoids $\mathbf{1 v - 9 v}$ to $\mathrm{IC}_{50}$ values of their structural analogues previously isolated from A. glutinosa $\mathbf{3 g}, \mathbf{5 g}, \mathbf{8 g}$ and 9g (Table 1) [16]. The statistical analysis of diarylheptanoids activity is presented in Table S2 in the Supporting information. 
The SAR analysis of $\mathbf{5 g}$ and $9 \mathrm{~g}$ from A. glutinosa and $\mathbf{5 v}$ and $9 \mathrm{v}$ from A. viridis revealed that hydroxyl groups at $\mathrm{C}-3^{\prime}$ and $\mathrm{C}-3^{\prime \prime}$ positions have a notable negative effect on the cytotoxicity of the tested compounds. Structurally analogous $\mathbf{5 v / 5 g}$ and $\mathbf{9 v} / \mathbf{9 g}$ pairs confirmed that the presence of 3 '- and $3 "-\mathrm{OH}$ groups significantly decreases activity which is in agreement with our previous findings [16]. Platyphyllenone (9v) exhibited stronger biological effect compared to its analogue hirsutenone (9g) since it lacks 3'- and 3"-OH groups; however its selectivity towards cancer cells was weak. Compound $\mathbf{5 v}$, which also lacks 3 '- and $3 "-\mathrm{OH}$ groups, showed stronger activity than its analogue 5-Omethylhirsutanonol (5g), but was also not selective towards cancer cells (Fig. 1; Table 1). Additionally, the presence of 4,5 double bond instead of a methoxy group in $9 \mathrm{v} / 9 \mathrm{~g}$ analogues had unfavorable effect on proliferation in NCI-H460 cells. The presence of carbonyl group at C-3 had positive effect on the biological activity of diarylheptanoids since 3v, 5v, 8v and 9v were considerably more potent than diarylheptanoids without C-3 carbonyl group (Fig. 1A). The same structure-activity relationship was reported earlier in A. glutinosa diarylheptanoids [16]. Compound $\mathbf{3 v}$ has one more apiose compared to platyphylloside (8g) but the two diarylheptanoids exhibited similar activity because carbonyl group has stronger influence than apiose addition (Table 1). An apiose moiety in 3v instead of a $p$-coumaroyl group in $\mathbf{3 g}$ negatively affected selectivity towards cancer cells. The presence of galloyl group in $\mathbf{8 v}$ compared to $p$-coumaroyl in $\mathbf{3 g}$ decreased cytotoxic activity. Additional galloyl group in $\mathbf{8 v}$ compared to $\mathbf{8 g}$ did not significantly influence activity but had a notable effect on selectivity.

To evaluate the potential of diarylheptanoids to induce cell death, NCI-H460 and HaCaT cells were treated with $15 \mu \mathrm{M}$ or $45 \mu \mathrm{M} \mathrm{5v}, \mathbf{9 v}, \mathbf{5 g}$ and $9 \mathrm{~g}$ for $48 \mathrm{~h}$ and subjected 
to AV/PI staining (Fig. 2). The $15 \mu \mathrm{M}$ concentration was approximate to $\mathrm{IC}_{50}$ values of investigated compounds based on the $72 \mathrm{~h}$ cytotoxicity assay performed in 96-well plates. For flow-cytometric analysis the cells were seeded in a higher density in 6-well plates and the treatment time for each diarylheptanoid was shorter. In order to compensate for this we additionally applied the $45 \mu \mathrm{M}$ concentration $\left(\sim 3 \mathrm{xIC}_{50}\right)$ to more easily achieve the investigated effect and compare it between the compounds. Treatment with $15 \mu \mathrm{M} \mathrm{5v}$ and $9 \mathrm{v}$ caused significant cell death induction which was not observed with $15 \mu \mathrm{M} \mathbf{5 g}$ and 9g. Especially prominent effect was obtained in 9v treated HaCaT cells (Fig. 2A). Application of higher concentration $(45 \mu \mathrm{M})$ resulted in significant cell death induced by all compounds in both cells lines. $\mathbf{5 v}$ showed considerably higher potency in HaCaT cells when compared to $5 \mathrm{~g}$ (Fig. 2B). Analogue pair 9v/9g had much higher apoptotic efficiency at $45 \mu \mathrm{M}$ in both cell lines compared to its $\mathbf{5 v / 5 g}$ counterpart, further suggesting the positive effect of 4,5 double bond on biological activity. The cell death effect observed with diarylheptanoids was apoptotic showing the increase of cell percentage in both early and late apoptosis which was followed by secondary necrosis when higher concentration $(45 \mu \mathrm{M})$ was applied. The statistical analysis of diarylheptanoids cell death inducing activity is presented in Table S3 in the Supporting information.

\subsection{The effect of diarylheptanoids on cell cycle kinetics in NCI-H460 and HaCaT cells}

Diarylheptanoids have been previously reported to significantly affect cell cycle kinetics. Cell cycle analysis on myricanone-treated HepG2 cells revealed $\mathrm{G}_{0} / \mathrm{G}_{1}$ phase 
arrest [25] which was also reported in another study on curcumin [26]. Myricanone was also shown to induce cell cycle arrest at different stages in HeLa and PC3 cells. HeLa cells displayed $G_{0} / G_{1}$ phase increase followed by $G_{2} / M$ decrease whereas in PC3 cells arrest occurred at S phase [27]. In neuroblastoma cells, diarylheptanoids from Alpinia officinarum induced $\mathrm{S}$ phase cell cycle arrest concurrently with an increased subG $_{0}$ cell population [28].

We subsequently studied how cytotoxicity of diarylheptanoids affects the cell cycle kinetics. The differences between $15 \mu \mathrm{M}$ and $45 \mu \mathrm{M} 48 \mathrm{~h}$ treatments with $\mathbf{5 v}, \mathbf{9 v}$, 5g and 9g were assessed by flow cytometry (Fig. 3). Representative flow-cytometric profiles of 9v treated NCI-H460 and HaCaT cells are shown in Fig. 3A. At $15 \mu \mathrm{M}$ treatment, $5 \mathbf{v}$ and $9 v$ notably perturbed cell cycle phases in both cell lines, which was especially prominent in HaCaT cells. Both compounds decreased the percentage of NCI$\mathrm{H} 460$ and HaCaT cells in $\mathrm{G}_{0} / \mathrm{G}_{1}$ phase (Fig. 3B) followed by significant increase in dead cells $\left(\mathrm{subG}_{0}\right.$ phase). Treatment with higher concentration $(45 \mu \mathrm{M})$ of diarylheptanoids from A. viridis completely disturbed the cell cycle in both cell lines causing major increase in $\mathrm{subG}_{0}$ phase cells. Diarylheptanoid 5g from A. glutinosa did not cause significant perturbation of the cell cycle phases. Compound $9 \mathrm{~g}$ was active only at $45 \mu \mathrm{M}$ concentration in HaCaT cells, leading to decrease in $\mathrm{G}_{0} / \mathrm{G}_{1}$ phase, while the amount of dead cells in subG $\mathrm{G}_{0}$ phase was increased. Cell cycle analysis was consistent with flowcytometric cell death analysis implying pro-apoptotic effect of diarylheptanoids since the increase in cell death was followed by increase in $s \mathrm{bG}_{0}$ (DNA fragmentation) and decrease in $\mathrm{G}_{0} / \mathrm{G}_{1}$ phase. The statistical analysis of diarylheptanoids cell cycle arresting activity is presented in Table S4 in the Supporting information. 


\subsection{Diarylheptanoids from $A$. viridis increased superoxide anion levels in NCI-H460 and HaCaT cells}

Reactive oxygen species (ROS) are produced in many pathological conditions such as cancers, cardiovascular, inflammatory diseases or autoimmune diseases [29-30], but also in physiological situations like cellular metabolism, signaling pathways including proliferation and migration [31-36]. Low amounts of ROS may suppress viruses, pathogens, and tumor proliferation exerting beneficial effects, while high amounts may damage the host cells and favor tumor progression [31, 36-37]. To test superoxide anion production, NCI-H460 and $\mathrm{HaCaT}$ cells were treated with $15 \mu \mathrm{M}$ diarylheptanoids $\mathbf{5 v}, \mathbf{9 v}, \mathbf{5 g}$ and $\mathbf{9 g}$ for $24 \mathrm{~h}$. Superoxide anion levels were detected by DHE staining and assessed by flow-cytometry and fluorescence microscopy (Fig. 4). Representative flow-cytometric profiles of $\mathbf{9 v}$ treated NCI-H460 and $\mathrm{HaCaT}$ cells are shown in Fig. 4A. Intensity of DHE fluorescence after $5 \mathbf{v}$ and $9 \mathbf{v}$ treatment significantly increased in both cell lines showing stronger effect than diarylheptanoids from $A$. glutinosa. The intracellular accumulation of superoxide anion was more pronounced in HaCaT cells, with 9v exhibiting the strongest effect compared to other compounds (Fig. 4B). These results were additionally confirmed by live DHE imaging (Fig. 4C). Depending on their chemical structure, various diarylheptanoids have been reported to act as pro- or antioxidants [14, 38-43]. Oregonin, another diarylheptanoid found in the Alnus genus has been reported to reduce production of ROS and increase expression of antioxidant-related genes in human macrophages [40]. This open-chain diarylheptanoid glycoside with 3-carbonyl and 5-xylosyloxy groups also possesses analogous chemical 
structure to compounds investigated in this study. The presence of $3^{\prime}$ and $3^{\prime \prime}-\mathrm{OH}$ groups, is likely responsible for the reduced pro-oxidant activity of $\mathbf{5 g}$ and $\mathbf{9 g}$, as well as ROSprotective properties of oregonin. Another structurally related diarylheptanoid from $A$. glutinosa which contains a p-coumaroyl group, $3 \mathrm{~g}$ was shown to efficiently antagonize cisplatin-induced superoxide anion production in NCI-H460 and $\mathrm{HaCaT}$ cells by increasing the expression of manganese superoxide dismutase (Mn-SOD) and hypoxiainducible factor-1 (HIF-1 $\alpha$ ) mRNA [14]. Its structural analogue without $p$-coumaroyl group, platyphylloside, was far less effective in ROS scavenging activity. SAR evaluation suggests that the influence of diarylheptanoids on intracellular oxidative status highly depends on minor variations in their chemical composition where the absence of hydroxyl groups at C-3' and C-3" in aryl moieties is highly advantageous for triggering superoxide production.

\subsection{Diarylheptanoids from $A$. viridis decreased mitochondrial transmembrane potential in NCI-H460 and HaCaT cells}

Mitochondria are responsible for vital cellular processes such as respiration, oxidative phosphorylation or apoptosis regulation and also represent the main intracellular source of ROS [44-45]. A variety of natural compounds, including quercetin, resveratrol, and diarylheptanoid curcumin, modulate mitochondrial functions by inhibiting organelle enzymes or metabolic pathways, altering ROS production, and expression of mitochondrial proteins. These compounds can act as both pro- and antioxidants and display pro-apoptotic activity by affecting $\Delta \Psi_{\mathrm{m}}$ and cytochrome c 
release from mitochondria or affecting the expression of pro-apoptotic and anti-apoptotic proteins [46-47]. In human glioblastoma and colorectal cancer cells, diarylheptanoid curcumin caused the release of cytochrome $\mathrm{c}$ and apoptosis-inducing factor from mitochondria [48-49], as well as a rapid decrease in $\Delta \Psi_{\mathrm{m}}$ in growing murine neural 2a (N2a) cells [50] subsequently followed by cell death. The effects of diarylheptanoids $\mathbf{5 v}$, 9v, 5g and 9g on $\Delta \Psi_{\mathrm{m}}$ were studied in NCI-H460 and HaCaT cells after treatment with $15 \mu \mathrm{M}$ compounds for $24 \mathrm{~h}$ (the same experimental setting as for the ROS production analysis). After treatment, cells were labeled with JC-1 and analyzed by flow-cytometry or imaged live (Fig. 5). Representative flow-cytometric profiles of $9 \mathrm{v}$ treated NCI-H460 and $\mathrm{HaCaT}$ cells are shown in Fig. 5A. Diarylheptanoid $\mathbf{9 v}$ had the strongest effect on the $\Delta \Psi_{\mathrm{m}}$ in $\mathrm{HaCaT}$ cells which is in accordance with the pro-apoptotic and pro-oxidative potential of this compound. Less notable effect on the mitochondria was observed after 5v treatment (Fig. 5B). Compound 9v along with its structural analogue 9g more prominently depolarized the mitochondrial membrane in $\mathrm{HaCaT}$ cells compared to $\mathbf{5 v} / \mathbf{5 g}$ analogue pair which possesses a methoxy group instead of 4,5 double bond, confirming again the earlier observed SAR pattern. However, similar effects on apoptosis following the same $15 \mu \mathrm{M}$ treatment were not observed in this cell line. Keratinocytes are considered as highly resistant toward environmental factors including oxidative stress [51], thus the survival of $\mathrm{HaCaT}$ cells could be attributed to their efficient defense mechanisms against cell death. Piskounova et al. demonstrated that mitochondrial mass and $\Delta \Psi_{\mathrm{m}}$ are significantly lower in circulating melanoma cells compared to subcutaneous tumors [52]. Circulating human melanoma cells have also been shown to have significantly higher cytoplasmic ROS levels than subcutaneous tumors which have 
elevated mitochondrial ROS content. Since mitochondrial respiration is one of the main sources of ROS, this raises the possibility that mitochondrial function in cells can be reduced in order to reduce ROS generation. A reduction in mitochondrial mass as a cell's compensation for increased ROS production could be one of the reasons behind the decline in $\Delta \Psi_{\mathrm{m}}$ after treatment with compounds investigated in this study. Additionally, it is possible that the majority of superoxide anions originate in the cytoplasm rather than mitochondria.

\section{Conclusion}

Nine diarylheptanoids, including a new compound $\mathbf{4 v}$, were isolated from the bark of A. viridis and investigated for their pro-apoptotic potential and selectivity towards cancer cells. Significant cytotoxicity was exhibited by compounds $3 \mathbf{v}, \mathbf{5 v}, 8 \mathbf{v}$ and $9 \mathbf{v}$, while $2 \mathbf{v}$ and $7 \mathbf{v}$ showed considerable selectivity although their activity was weak. The inhibitory effect of compounds $\mathbf{5 v}$ and $\mathbf{9 v}$ was compared to structurally analogous diarylheptanoids $5 \mathrm{~g}$ and $\mathbf{9 g}$ previously isolated from A. glutinosa. $5 \mathrm{v}$ and $9 \mathrm{v}$ displayed more potent cytotoxic activity than their analogues from black alder confirming that the presence of 3' and 3"-OH groups has negative influence on cytotoxic activity. Selectivity of green alder diarylheptanoids towards cancer cells was poor in comparison with their black alder analogues. Carbonyl group at C-3 also positively affected the efficiency of $3 v, 5 v, 8 v$ and $9 v$ which proved considerably more potent than compounds without a C-3 carbonyl group. 4,5 double bond instead of a methoxy group in $9 \mathrm{v}$ and $9 \mathrm{~g}$ positively influenced cell growth inhibition and pro-apoptotic potential. Minor differences in 
chemical structure had a striking effect on the ability of compounds to modify essential cellular processes including cell cycle, apoptosis and redox status, and additionally determined the selectivity of investigated compounds towards cancer cells. Since diarylheptanoids are prominent metabolites in many medicinal plants, established patterns in structure-activity relationship could be useful in identifying candidates with potentially high cytotoxicity or selectivity among a large number of isolated natural compounds for further anticancer studies. Following the findings from this investigation, chemical synthesis of diarylheptanoids more potent and selective towards cancer cells could be undertaken.

\section{Acknowledgements}

This research was supported by the Ministry of Education, Science and Technological Development of Serbia (grant nos. III 41031 and 172053).

\section{Conflict of interest}

The authors declare no conflict of interest.

\section{Figure legends}

Fig. 1. Chemical structures of diarylheptanoids isolated from the barks of A. viridis (A) and A. glutinosa $(\mathbf{B})$.

Fig. 2. Cell death induction by diarylheptanoids. Annexin-V/PI analysis was performed in NCI-H460 and $\mathrm{HaCaT}$ cells treated with $15 \mu \mathrm{M}$ and $45 \mu \mathrm{M}$ diarylheptanoids for $48 \mathrm{~h}$. (A) Representative flow-cytometric profiles of $9 \mathbf{v}$ treated cells. (B) The percentage of 
viable, early apoptotic, late apoptotic and necrotic cells after treatment with $5 \mathbf{v}, 5 \mathrm{~g}, \mathbf{9 v}$ and 9g. 10,000 cells per each sample were analyzed for green fluorescence (Annexin-VFITC, FL1-H) and red fluorescence (Propidium Iodide, FL2-H) by flow-cytometry.

Fig. 3. Analysis of the cell cycle kinetics after diarylheptanoids' treatment. Cell cycle was studied by PI binding in NCI-H460 and HaCaT cells treated with $15 \mu \mathrm{M}$ and $45 \mu \mathrm{M}$ diarylheptanoids for $48 \mathrm{~h}$. (A) Representative flow-cytometric profiles of $9 \mathrm{v}$ treated cells. $\mathrm{Y}$-axis of the flow-cytometric profile represents cell numbers and $\mathrm{X}$-axis shows DNA content detected by PI. (B) The percentage of cells in subG $\mathrm{s}_{0}, \mathrm{G}_{0} / \mathrm{G}_{1}, \mathrm{~S}$ and $\mathrm{G}_{2} / \mathrm{M}$ phase after treatment with $5 \mathbf{v}, 5 \mathbf{5 g}, 9 \mathbf{v}$ and $9 \mathrm{gg}$. Histograms illustrate one representative experiment.

Fig. 4. Superoxide anion production induced by diarylheptanoids. DHE labeling was performed in NCI-H460 and $\mathrm{HaCaT}$ cells treated with $15 \mu \mathrm{M}$ diarylheptanoids for $24 \mathrm{~h}$. (A) Representative flow-cytometric profiles of $9 \mathrm{v}$ treated cells. Percentages correspond to DHE stained cells within the selected region of interest. (B) The percentage of DHE stained cells within the selected region of interest after treatment with $\mathbf{5 v}, \mathbf{5 g}, \mathbf{9 v}$ and $9 \mathrm{~g}$. Statistical significance is presented as $\mathrm{p}<0.0001(* * * *)$ and refers to untreated cells. (C) NCI-H460 and HaCaT cells labeled with DHE and imaged live on a fluorescent microscope. Scale bar $=50 \mu \mathrm{m}$.

Fig. 5. Changes in mitochondrial transmembrane potential induced by diarylheptanoids. JC-1 labeling was performed in NCI-H460 and HaCaT cells treated with $15 \mu \mathrm{M}$ diarylheptanoids for $24 \mathrm{~h}$. (A) Representative flow-cytometric profiles of $9 \mathrm{v}$ treated cells. Percentages correspond to a shift in green to red fluorescence ratio in JC-1 stained cells within the selected region of interest. (B) The percentage of JC-1 stained cells with a shift 
in green to red fluorescence ratio within the selected region of interest after treatment with $\mathbf{5 v}, 5 \mathbf{g}, 9 \mathbf{v}$ and $9 \mathrm{~g}$. Statistical significance is presented as $\mathrm{p}<0.001(* * *)$ and p $<0.0001(* * * *)$ and refers to untreated cells. (C) NCI-H460 and HaCaT cells labeled with JC-1 and imaged live on a fluorescent microscope. Loss of $\Delta \Psi_{\mathrm{m}}$ after treatment reduces the amount of mitochondrial dye aggregates (red), which is accompanied by accumulation of monomeric form of JC-1 in the cytoplasm (green). Scale bar $=50 \mu \mathrm{m}$.

\section{References}

[1] P.W. Ball, T.G. Tutin, V.H. Heywood, N.A. Burges, D.H. Valentine, S.M. Walters, D.A. Webb, Flora Europaea, Cambridge Univesity Press, London, 1964.

[2] B. Jovanovic, Flora of Serbia, Serbian Academy of Sciences and Arts, Belgrade, 1970.

[3] T. Stevic, K. Savikin, G. Zdunic, T. Stanojkovic, Z. Juranic, T. Jankovic, N. Menkovic, Antioxidant, cytotoxic, and antimicrobial activity of Alnus incana (L.) ssp. incana Moench and A. viridis (Chaix) DC ssp. viridis extracts, J Med Food 13 (2010) 700-704.

[4] M.Y. Chung, M.C. Rho, S.W. Lee, H.R. Park, K. Kim, I.A. Lee, D.H. Kim, K.H. Jeune, H.S. Lee, Y.K. Kim, Inhibition of diacylglycerol acyltransferase by betulinic acid from Alnus hirsuta, Planta Med 72 (2006) 267-269.

[5] M. Kuroyanagi, M. Shimomae, Y. Nagashima, N. Muto, T. Okuda, N. Kawahara, T. Nakane, T. Sano, New diarylheptanoids from Alnus japonica and their antioxidative activity, Chem Pharm Bull (Tokyo) 53 (2005) 1519-1523.

[6] S. Dahija, J. Cakar, D. Vidic, M. Maksimovic, A. Paric, Total phenolic and flavonoid contents, antioxidant and antimicrobial activities of Alnus glutinosa (L.) Gaertn., Alnus incana (L.) Moench and Alnus viridis (Chaix) DC. extracts, Nat Prod Res 28 (2014) 2317-2320.

[7] H. Matsuda, A. Ishikado, N. Nishida, K. Ninomiya, H. Fujiwara, Y. Kobayashi, M. Yoshikawa, Hepatoprotective, superoxide scavenging, and antioxidative activities of aromatic constituents from the bark of Betula platyphylla var. japonica, Bioorg Med Chem Lett 8 (1998) 2939-2944.

[8] N.H. Tung, S.K. Kim, J.C. Ra, Y.Z. Zhao, D.H. Sohn, Y.H. Kim, Antioxidative and hepatoprotective diarylheptanoids from the bark of Alnus japonica, Planta Med 76 (2010) 626-629. 
[9] H.-B. Lee, H.-K. Lee, J.-R. Kim, Y.-J. Ahn, Anti-Helicobacter pylori diarylheptanoid identified in the rhizome of Alpinia officinarum, Journal of the Korean Society for Applied Biological Chemistry 52 (2009) 367-370.

[10] N.H. Tung, H.J. Kwon, J.H. Kim, J.C. Ra, Y. Ding, J.A. Kim, Y.H. Kim, Antiinfluenza diarylheptanoids from the bark of Alnus japonica, Bioorg Med Chem Lett 20 (2010) 1000-1003.

[11] M. Novakovic, M. Stankovic, I. Vuckovic, N. Todorovic, S. Trifunovic, V. Tesevic, V. Vajs, S. Milosavljevic, Diarylheptanoids from Alnus glutinosa bark and their chemoprotective effect on human lymphocytes DNA, Planta Med 79 (2013) 499-505.

[12] V. Mshvildadze, J. Legault, S. Lavoie, C. Gauthier, A. Pichette, Anticancer diarylheptanoid glycosides from the inner bark of Betula papyrifera, Phytochemistry 68 (2007) 2531-2536.

[13] S.E. Choi, K.H. Kim, J.H. Kwon, S.B. Kim, H.W. Kim, M.W. Lee, Cytotoxic activities of diarylheptanoids from Alnus japonica, Arch Pharm Res 31 (2008) 1287-1289.

[14] J. Dinic, M. Novakovic, A. Podolski-Renic, S. Stojkovic, B. Mandic, V. Tesevic, V. Vajs, A. Isakovic, M. Pesic, Antioxidative activity of diarylheptanoids from the bark of black alder (Alnus glutinosa) and their interaction with anticancer drugs, Planta Med 80 (2014) 1088-1096.

[15] J. Dinic, T. Randelovic, T. Stankovic, M. Dragoj, A. Isakovic, M. Novakovic, M. Pesic, Chemo-protective and regenerative effects of diarylheptanoids from the bark of black alder (Alnus glutinosa) in human normal keratinocytes, Fitoterapia 105 (2015) 169-176.

[16] M. Novakovic, M. Pesic, S. Trifunovic, I. Vuckovic, N. Todorovic, A. PodolskiRenic, J. Dinic, S. Stojkovic, V. Tesevic, V. Vajs, S. Milosavljevic, Diarylheptanoids from the bark of black alder inhibit the growth of sensitive and multi-drug resistant non-small cell lung carcinoma cells, Phytochemistry 97 (2014) 46-54.

[17] M. Novakovic, M. Stankovic, I. Vuckovic, N. Todorovic, S. Trifunovic, D. Apostolovic, B. Mandic, M. Veljic, P. Marin, V. Tesevic, V. Vajs, S. Milosavljevic, Diarylheptanoids from green alder bark and their potential for DNA protection, Chem Biodivers 11 (2014) 872-885.

[18] S. Seo, Y. Tomita, K. Tori, Y. Yoshimura, Determination of the absolute configuration of a secondary hydroxy group in a chiral secondary alcohol using glycosidation shifts in carbon-13 nuclear magnetic resonance spectroscopy, J Am Chem Soc 100 (1978) 3331-3339

[19] T. Suga, S. Ohta, T. Hivata, T. Aoki, Absolute configuration of diarylheptanoid xyloside, oregonine, isolated from the female flowers of Alnus serrulatoides, Chem Lett (1982) 895-898.

[20] M. Nagai, N. Kenmochi, M. Fujita, N. Furukawa, T. Inoue, Studies on the constituents of Aceraceae plants. VI. revised stereochemistry of (-)-centrolobol and new glycosides of Acer nikoense, Chem. Pharm. Bull 34 (1986) 1056-1060.

[21] D. Park, H.J. Kim, S.Y. Jung, C.S. Yook, C. Jin, Y.S. Lee, A new diarylheptanoid glycoside from the stem bark of Alnus hirsuta and protective effects of 
diarylheptanoid derivatives in human HepG2 cells, Chem Pharm Bull (Tokyo) 58 (2010) 238-241.

[22] S. Ohta, T. Aoki, T. Hirata, T. Suga, The structures of four diarylheptanoid glycosides from the female flowers of Alnus serrulatoides, Journal of the Chemical Society, Perkin Transactions 1 (1984) 1635-1642.

[23] P. Skehan, R. Storeng, D. Scudiero, A. Monks, J. McMahon, D. Vistica, J.T. Warren, H. Bokesch, S. Kenney, M.R. Boyd, New colorimetric cytotoxicity assay for anticancer-drug screening, J Natl Cancer Inst 82 (1990) 1107-1112.

[24] M. Reers, S.T. Smiley, C. Mottola-Hartshorn, A. Chen, M. Lin, L.B. Chen, Mitochondrial membrane potential monitored by JC-1 dye, Methods Enzymol 260 (1995) 406-417.

[25] A. Paul, J. Das, S. Das, A. Samadder, A.R. Khuda-Bukhsh, Anticancer potential of myricanone, a major bioactive component of Myrica cerifera: novel signaling cascade for accomplishing apoptosis, J Acupunct Meridian Stud 6 (2013) 188198.

[26] H.-q. Li, L.-j. Jin, F.-f. Wu, X.-y. Li, J.-s. You, Z.-h. Cao, D. Li, Y.-p. Xu, Effect of curcumin on proliferation, cell cycle, and caspases and MCF-7 cells Afr. J. Pharm. Pharmacol. 6 (2012) 864-870.

[27] A. Paul, S. Das, J. Das, A. Samadder, K. Bishayee, R. Sadhukhan, A.R. KhudaBukhsh, Diarylheptanoid-myricanone isolated from ethanolic extract of Myrica cerifera shows anticancer effects on HeLa and PC3 cell lines: signalling pathway and drug-DNA interaction, J Integr Med 11 (2013) 405-415.

[28] K. Tabata, Y. Yamazaki, M. Okada, K. Fukumura, A. Shimada, Y. Sun, K. Yasukawa, T. Suzuki, Diarylheptanoids derived from Alpinia officinarum induce apoptosis, S-phase arrest and differentiation in human neuroblastoma cells, Anticancer Res 29 (2009) 4981-4988.

[29] T.J. Guzik, R. Korbut, T. Adamek-Guzik, Nitric oxide and superoxide in inflammation and immune regulation, J Physiol Pharmacol 54 (2003) 469-487.

[30] A. Perl, P. Gergely, Jr., K. Banki, Mitochondrial dysfunction in T cells of patients with systemic lupus erythematosus, Int Rev Immunol 23 (2004) 293-313.

[31] M. Valko, D. Leibfritz, J. Moncol, M.T. Cronin, M. Mazur, J. Telser, Free radicals and antioxidants in normal physiological functions and human disease, Int J Biochem Cell Biol 39 (2007) 44-84.

[32] W. Droge, Free radicals in the physiological control of cell function, Physiol Rev 82 (2002) 47-95.

[33] K. Nakamura, K. Yube, A. Miyatake, J.C. Cambier, M. Hirashima, Involvement of CD4 D3-D4 membrane proximal extracellular domain for the inhibitory effect of oxidative stress on activation-induced CD4 down-regulation and its possible role for T cell activation, Mol Immunol 39 (2003) 909-921.

[34] M. Los, W. Droge, K. Stricker, P.A. Baeuerle, K. Schulze-Osthoff, Hydrogen peroxide as a potent activator of $\mathrm{T}$ lymphocyte functions, Eur J Immunol 25 (1995) 159-165.

[35] T.L. Deem, J.M. Cook-Mills, Vascular cell adhesion molecule 1 (VCAM-1) activation of endothelial cell matrix metalloproteinases: role of reactive oxygen species, Blood 104 (2004) 2385-2393. 
[36] P. Pacher, J.S. Beckman, L. Liaudet, Nitric oxide and peroxynitrite in health and disease, Physiol Rev 87 (2007) 315-424.

[37] S. Reuter, S.C. Gupta, M.M. Chaturvedi, B.B. Aggarwal, Oxidative stress, inflammation, and cancer: how are they linked?, Free Radic Biol Med 49 (2010) 1603-1616.

[38] J.E. Kim, A.R. Kim, H.Y. Chung, S.Y. Han, B.S. Kim, J.S. Choi, In vitro peroxynitrite scavenging activity of diarylheptanoids from Curcuma longa, Phytother Res 17 (2003) 481-484.

[39] E.K. Song, H. Cho, J.S. Kim, N.Y. Kim, N.H. An, J.A. Kim, S.H. Lee, Y.C. Kim, Diarylheptanoids with free radical scavenging and hepatoprotective activity in vitro from Curcuma longa, Planta Med 67 (2001) 876-877.

[40] A. Lundqvist, L.U. Magnusson, C. Ullstrom, J. Krasilnikova, G. Telysheva, T. Dizhbite, L.M. Hulten, Oregonin reduces lipid accumulation and proinflammatory responses in primary human macrophages, Biochem Biophys Res Commun 458 (2015) 693-699.

[41] J. Ravindran, G.V. Subbaraju, M.V. Ramani, B. Sung, B.B. Aggarwal, Bisdemethylcurcumin and structurally related hispolon analogues of curcumin exhibit enhanced prooxidant, anti-proliferative and anti-inflammatory activities in vitro, Biochem Pharmacol 79 (2010) 1658-1666.

[42] A.J. Leon-Gonzalez, N. Acero, D. Munoz-Mingarro, M. Lopez-Lazaro, C. Martin-Cordero, Cytotoxic activity of hirsutanone, a diarylheptanoid isolated from Alnus glutinosa leaves, Phytomedicine 21 (2014) 866-870.

[43] H. Akazawa, Y. Fujita, N. Banno, K. Watanabe, Y. Kimura, A. Manosroi, J. Manosroi, T. Akihisa, Three new cyclic diarylheptanoids and other phenolic compounds from the bark of Myrica rubra and their melanogenesis inhibitory and radical scavenging activities, J Oleo Sci 59 (2010) 213-221.

[44] L. Gibellini, E. Bianchini, S. De Biasi, M. Nasi, A. Cossarizza, M. Pinti, Natural Compounds Modulating Mitochondrial Functions, Evid Based Complement Alternat Med 2015 (2015) 527209.

[45] M. Rigoulet, E.D. Yoboue, A. Devin, Mitochondrial ROS generation and its regulation: mechanisms involved in $\mathrm{H}(2) \mathrm{O}(2)$ signaling, Antioxid Redox Signal 14 (2011) 459-468.

[46] T.J. Lee, O.H. Kim, Y.H. Kim, J.H. Lim, S. Kim, J.W. Park, T.K. Kwon, Quercetin arrests G2/M phase and induces caspase-dependent cell death in U937 cells, Cancer Lett 240 (2006) 234-242.

[47] S.Y. Chien, Y.C. Wu, J.G. Chung, J.S. Yang, H.F. Lu, M.F. Tsou, W.G. Wood, S.J. Kuo, D.R. Chen, Quercetin-induced apoptosis acts through mitochondrialand caspase-3-dependent pathways in human breast cancer MDA-MB-231 cells, Hum Exp Toxicol 28 (2009) 493-503.

[48] S. Karmakar, N.L. Banik, S.J. Patel, S.K. Ray, Curcumin activated both receptormediated and mitochondria-mediated proteolytic pathways for apoptosis in human glioblastoma T98G cells, Neurosci Lett 407 (2006) 53-58.

[49] R. Gogada, M. Amadori, H. Zhang, A. Jones, A. Verone, J. Pitarresi, S. Jandhyam, V. Prabhu, J.D. Black, D. Chandra, Curcumin induces Apaf-1dependent, p21-mediated caspase activation and apoptosis, Cell Cycle 10 (2011) 4128-4137. 
[50] N.R. Jana, P. Dikshit, A. Goswami, N. Nukina, Inhibition of proteasomal function by curcumin induces apoptosis through mitochondrial pathway, J Biol Chem 279 (2004) 11680-11685.

[51] E. Bakondi, M. Gonczi, E. Szabo, P. Bai, P. Pacher, P. Gergely, L. Kovacs, J. Hunyadi, C. Szabo, L. Csernoch, L. Virag, Role of intracellular calcium mobilization and cell-density-dependent signaling in oxidative-stress-induced cytotoxicity in HaCaT keratinocytes, J Invest Dermatol 121 (2003) 88-95.

[52] E. Piskounova, M. Agathocleous, M.M. Murphy, Z. Hu, S.E. Huddlestun, Z. Zhao, A.M. Leitch, T.M. Johnson, R.J. DeBerardinis, S.J. Morrison, Oxidative stress inhibits distant metastasis by human melanoma cells, Nature 527 (2015) 186-191. 
Table 1. Cytotoxic effect and selectivity of diarylheptanoids from A. viridis compared to diarylheptanoids from A. glutinosa [16] in NCI-H460 and HaCaT cells.

\begin{tabular}{|c|c|c|c|}
\hline Species & Compound & $\begin{array}{l}\mathrm{IC}_{50}(\mu \mathrm{M})^{\mathrm{a}} \\
\text { NCI-H460 }\end{array}$ & $\begin{array}{c}\mathrm{IC}_{50}(\mu \mathrm{M})^{\mathrm{a}} \\
\mathrm{HaCaT}\end{array}$ \\
\hline \multirow{9}{*}{ A. viridis } & $\mathbf{1 v}$ & $295.5 \pm 11.0$ & 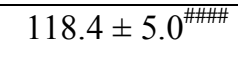 \\
\hline & $2 v$ & $69.5 \pm 4.5$ & $132.5 \pm 12.0^{* * * *}$ \\
\hline & $3 v$ & $21.8 \pm 0.8$ & $7.0 \pm 0.2^{\#}$ \\
\hline & $4 v$ & $388.9 \pm 4.0$ & $128.9 \pm 5.0^{\# \# \# \#}$ \\
\hline & $5 v$ & $14.4 \pm 0.3$ & $8.9 \pm 0.8$ \\
\hline & $6 v$ & $167.9 \pm 6.0$ & $147.4 \pm 3.0^{\# \# \# ~}$ \\
\hline & $7 v$ & $85.5 \pm 17.0$ & $152.4 \pm 4.0^{* * * * *}$ \\
\hline & $8 v$ & $31.8 \pm 2.3$ & $34.9 \pm 1.5$ \\
\hline & 9v & $8.2 \pm 0.1$ & $9.1 \pm 0.6$ \\
\hline \multirow{4}{*}{ A. glutinosa } & $3 g$ & $19.9 \pm 1.1$ & $31.3 \pm 1.4$ \\
\hline & $5 g$ & $29.7 \pm 0.7$ & $141.9 \pm 1.7^{* * * * *}$ \\
\hline & $8 g$ & $28.1 \pm 1.3$ & $8.7 \pm 2.3^{\# \# \#}$ \\
\hline & $9 \mathrm{~g}$ & $19.2 \pm 0.3$ & $43.2 \pm 1.9^{* * * * *}$ \\
\hline
\end{tabular}

${ }^{a} \mathrm{IC}_{50}$ values were calculated from three independent experiments (average \pm standard deviation). ${ }^{*}$ selectivity

\# no selectivity 
Figure 1.

A<smiles>Oc1ccc(CC[C@H](O)C[C@H](O)CCc2ccc(O)cc2)cc1</smiles><smiles>[R8]C(CCc1ccc(O)cc1)CC([R8])([R5])CCc1ccc(O)cc1</smiles>

2v: $\mathbf{R}_{1}=\beta$-D-Apif- $\left[1 \rightarrow\right.$ 6]- $\beta$-D-Glcp $; \mathbf{R}_{2}=\mathbf{H} ; \mathbf{R}_{3}=\mathbf{H}$ $4 \mathrm{v}: \mathbf{R}_{1}=\mathbf{H} ; \mathbf{R}_{2}=\alpha$-L-Araf $-[1 \rightarrow 6]-\beta-\mathrm{D}-\mathrm{Glc} p ; \mathbf{R}_{3}=\mathbf{H}$ 6v: $\mathbf{R}_{1}=\beta$-D-GIc $p ; \mathbf{R}_{2}=\mathbf{H} ; \mathbf{R}_{3}=\mathbf{O H}$

$7 \mathrm{v}: \mathbf{R}_{1}=\alpha$-L-Araf $-[1 \rightarrow 6]-\beta-\mathrm{D}-\mathrm{Glc} p ; \mathbf{R}_{2}=\mathbf{H} ; \mathbf{R}_{3}=\mathbf{H}$<smiles>[R]C(CCc1ccc(O)cc1)CC(=O)CCc1ccc(O)cc1</smiles><smiles>O=C(/C=C/CCc1ccc(O)cc1)CCc1ccc(O)cc1</smiles>
$9 \mathrm{v}$ $\alpha$-L-Araf $-[1 \rightarrow 6]-\beta-D-G I c p$

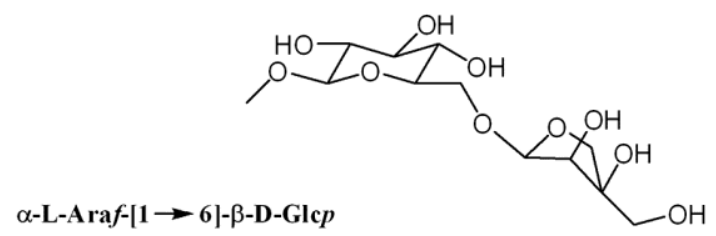

$\beta$-D-Glcp-6-galloyl

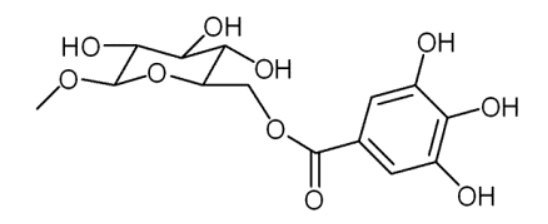

$\beta$-D-Apif-[1 $\rightarrow$ 6]- $\beta$-D-GIc $p$

$$
\mathrm{COH}_{\mathrm{O}}^{\mathrm{OOH}}
$$

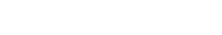

B<smiles>O=C(CCc1ccc(O)cc1)CC(CCc1ccc(O)cc1)OC1OC2OC1C(COC(=O)/C=C/c1ccc(O)cc1)C(O)C2O</smiles><smiles>[R]c1cc(CCC(=O)CC([R7])CCc2ccc(O)c([R])c2)ccc1O</smiles><smiles>O=C(/C=C/CCc1ccc(O)c(O)c1)CCc1ccc(O)c(O)c1</smiles>

9g 
Figure 2.

A
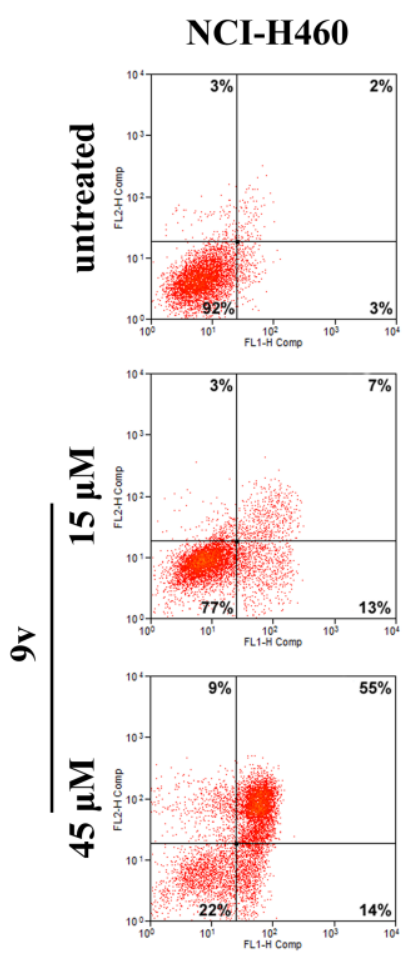

B
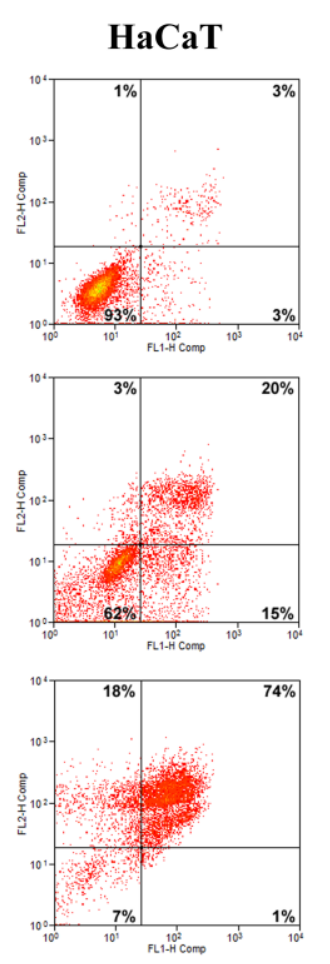
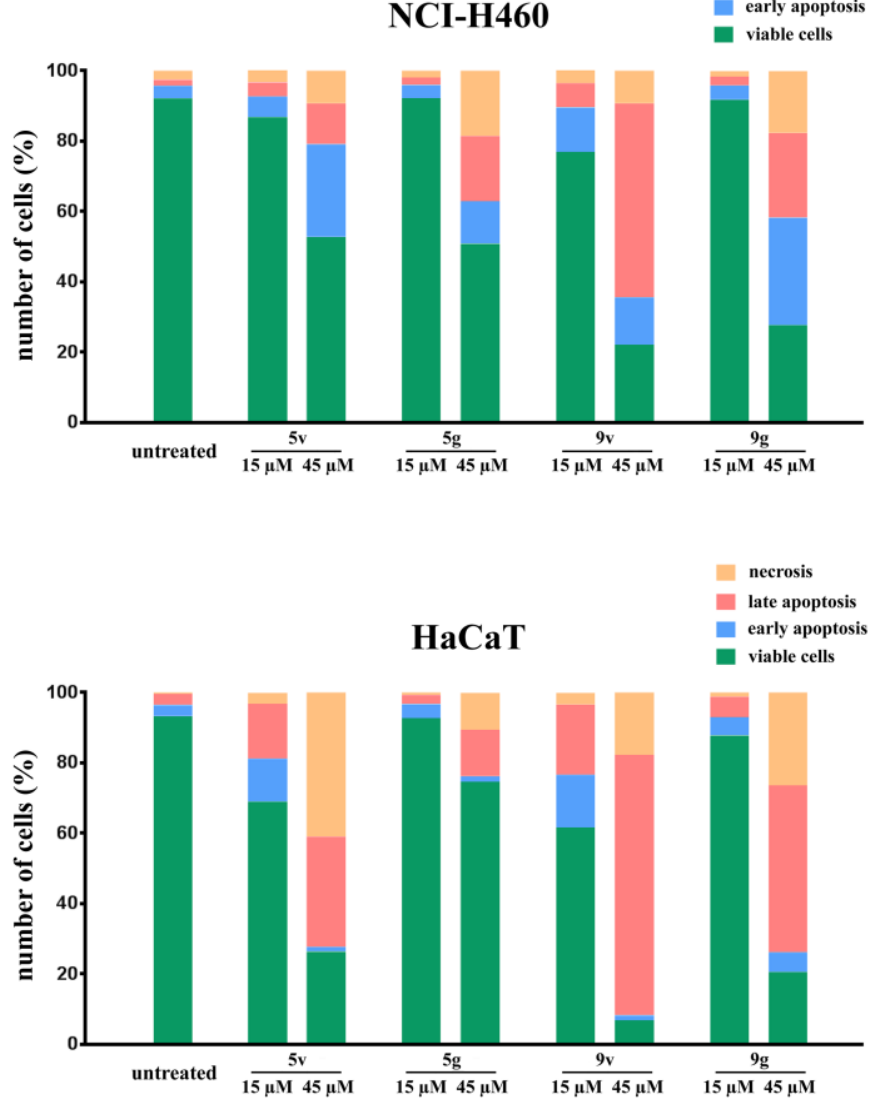
Figure 3.
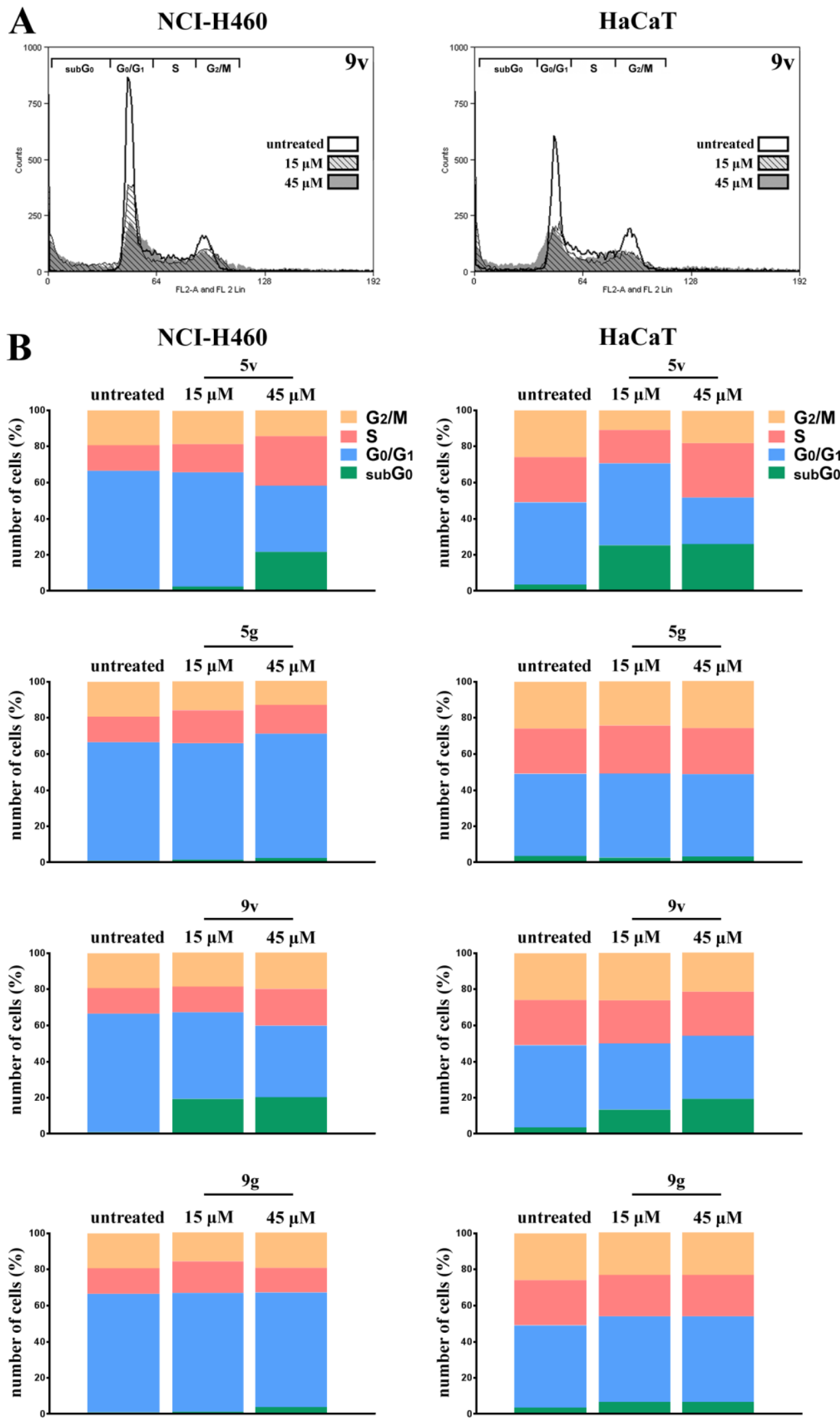
Figure 4.

A
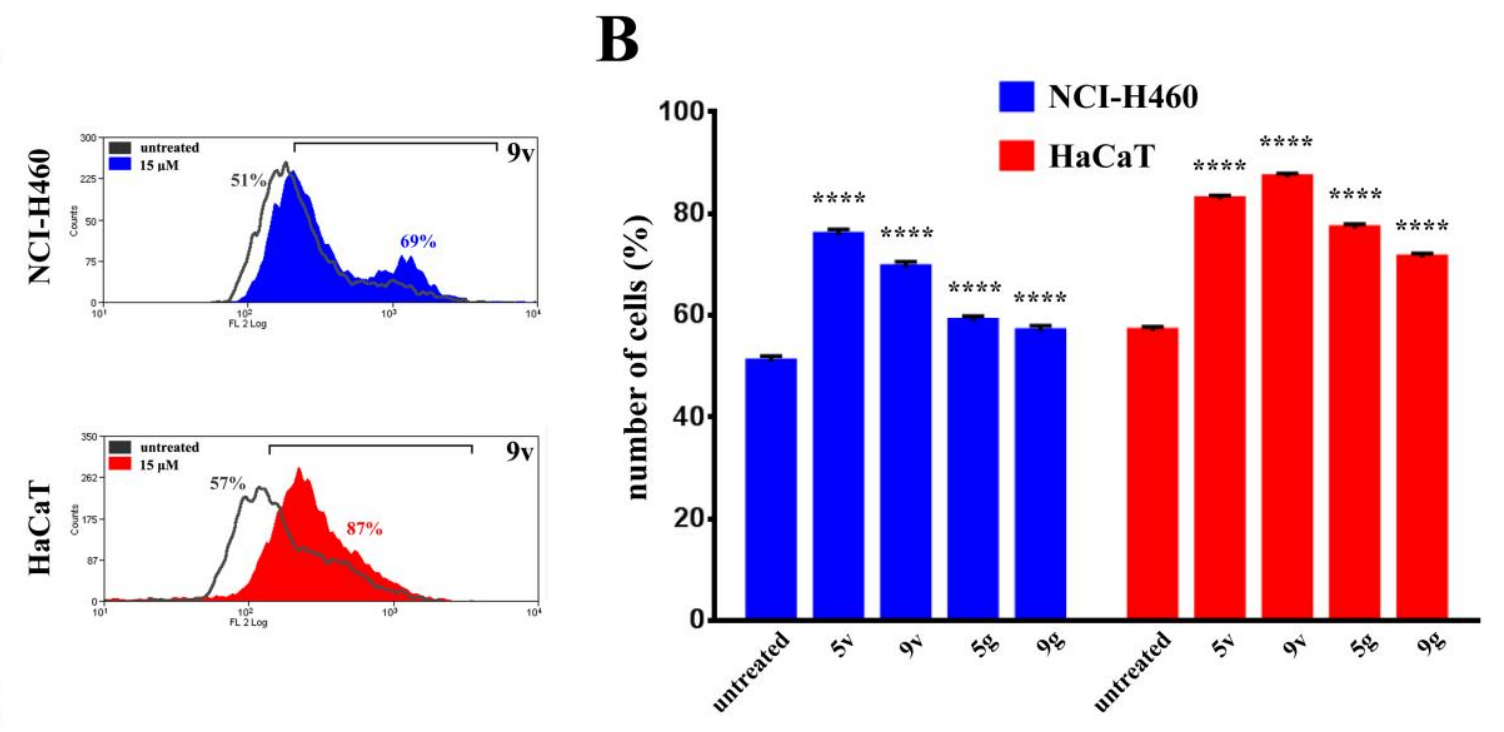

C
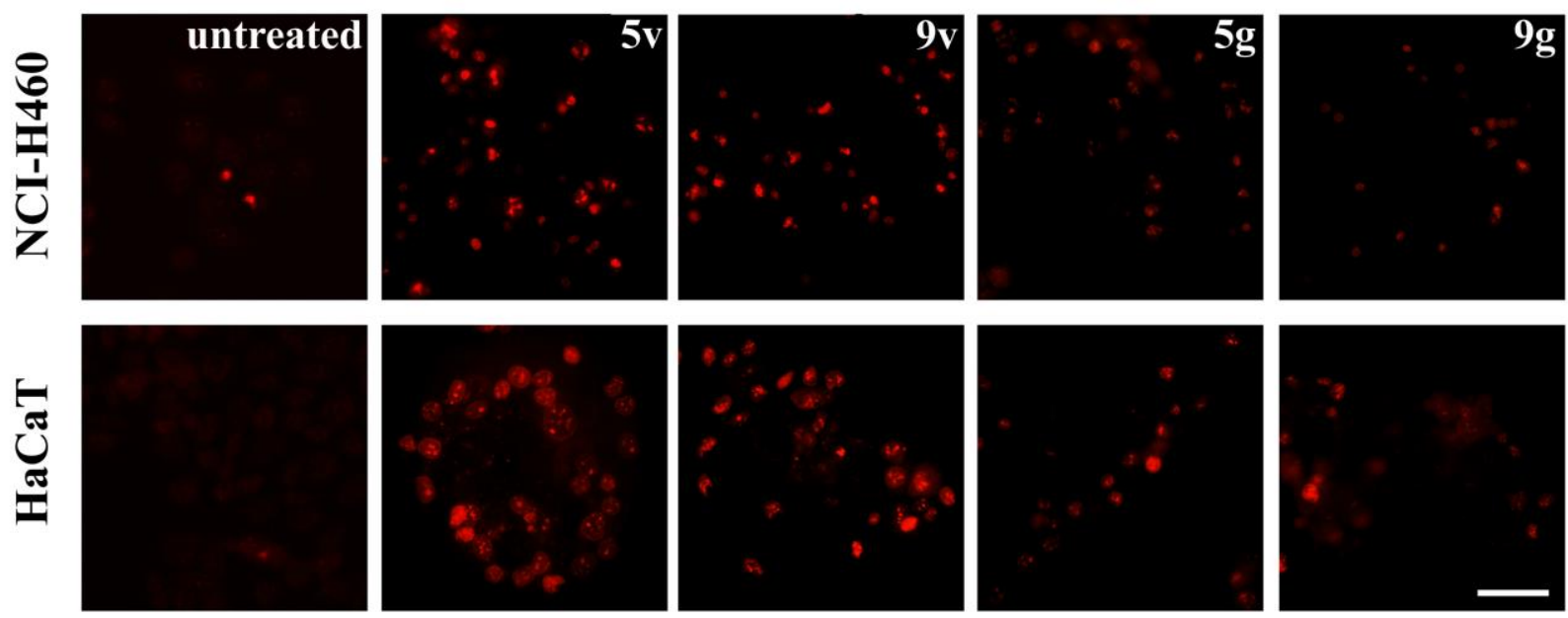
Figure 5.

A
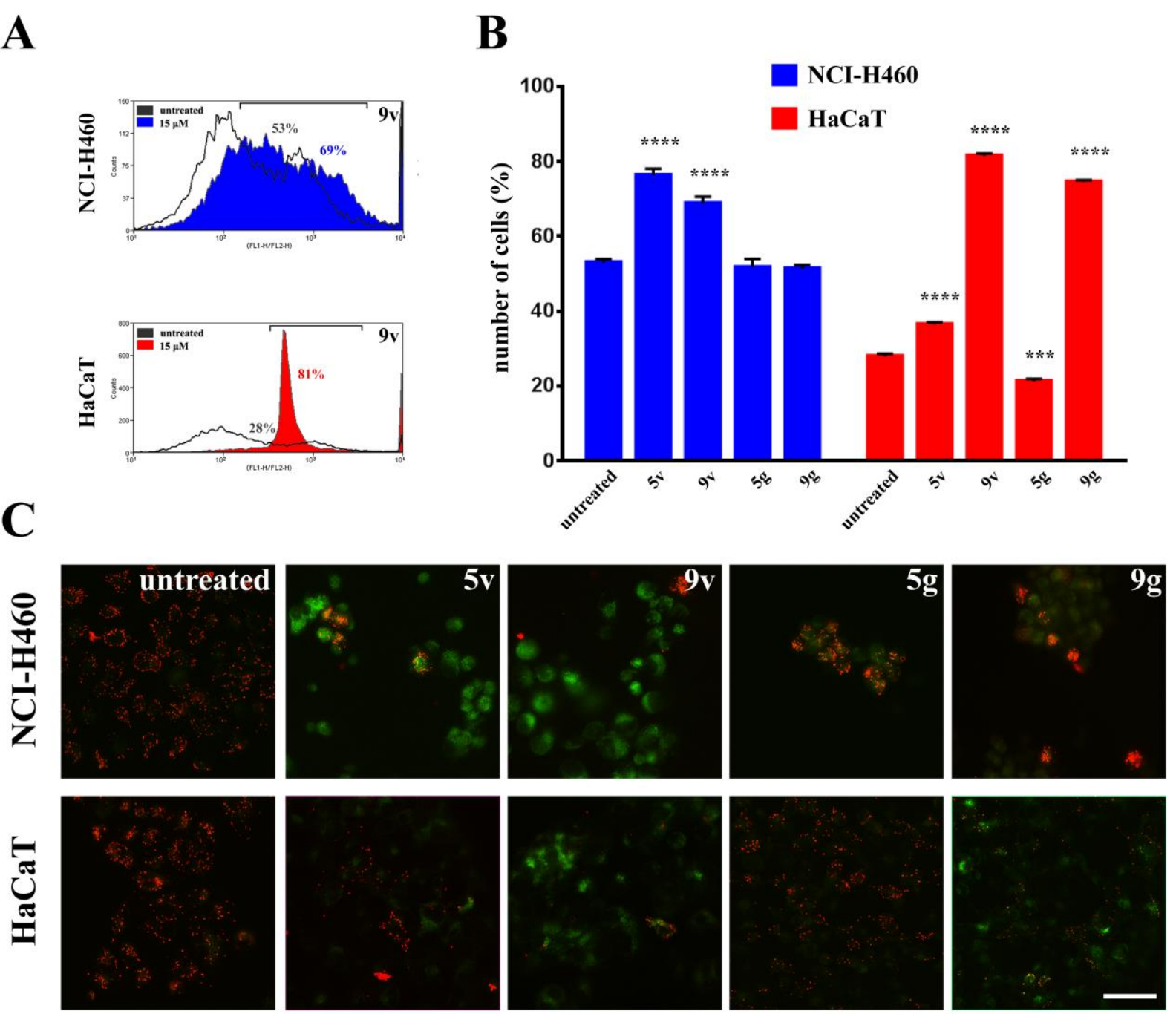